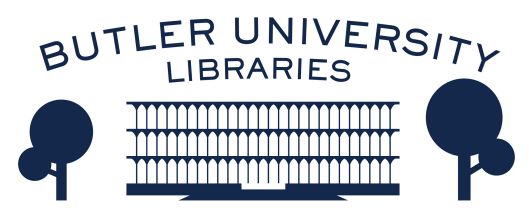

Journal of Hindu-Christian Studies

\title{
The Androgynous Visual Piety of the Mother and Sri Aurobindo and St. Clare and St. Francis
}

\author{
Patrick Beldio \\ The Catholic University of America
}

Follow this and additional works at: https://digitalcommons.butler.edu/jhcs

\section{Recommended Citation}

Beldio, Patrick (2015) "The Androgynous Visual Piety of the Mother and Sri Aurobindo and St. Clare and St. Francis," Journal of Hindu-Christian Studies: Vol. 28, Article 4.

Available at: https://doi.org/10.7825/2164-6279.1603

The Journal of Hindu-Christian Studies is a publication of the Society for Hindu-Christian Studies. The digital version is made available by Digital Commons @ Butler University. For questions about the Journal or the Society, please contact cbauman@butler.edu. For more information about Digital Commons @ Butler University, please contact digitalscholarship@butler.edu. 


\title{
The Androgynous Visual Piety of the Mother and Sri Aurobindo and St. Clare and St. Francis
}

\author{
Patrick Beldio \\ The Catholic University of America
}

\section{INTRODUCTION}

When one critically compares the Mother and Sri Aurobindo of Pondicherry, India with St. Clare and St. Francis of Assisi, Italy, one notices that the women are essential to manifesting the work and lives of the men. In fact, these two couples ultimately model a unity of gender, power, love, and work that is quite rare in any time or place. The theme of androgyny, therefore, emerges as an important lens through which to interpret their work together as celibate spiritual partners. As I will demonstrate, the theme of androgyny is seen, not only in their written texts, but equally and to some degree more powerfully in their shared use of fashion, art, architecture, and visual culture.

In the interest of hermeneutical transparency, I am influenced by the approach developed by David Morgan and others, who argue that religious belief can be reliably studied and understood by attending to what believers do with visual culture, and to what visual culture does to believers to shape belief. These dynamics include what Morgan calls "visual piety," which is "the visual formation and practice of religious belief" through understanding not only the nature of images

Patrick Beldio holds an M.F.A. in sculpture, an M.A. in Catholic Systematic Theology, and is currently a Ph.D. candidate in the Religion and Culture program at the Catholic University of America in Washington, D.C. His areas of expertise are studio art practice and education, religion and art, visual culture of religion, and twentieth-century Indian religious traditions, especially the Integral Yoga of the Mother and Sri Aurobindo. Other areas of academic interest are Hindu Art and Architecture, Catholic Art and Architecture, and Franciscan studies. He has published an article on his creative process in The Arts in Religious and Theological Studies journal and a review of an art exhibit at the Guggenheim Museum, NYC in the Material Religion journal. His artwork is in private and public collections across the United States. He is also working to complete a 39-foot tall bronze sculpture for a new Sanctuary designed by Philip Ritchie for Sufism Reoriented in Walnut Creek, CA. His future academic projects include a critical correlation of the aesthetic principles of the Integral Yoga with some current values of the art world in the United States, and a more lengthy study comparing the use of art and visual culture in the Integral Yoga and Franciscan spirituality as lived by their founders. He will also continue to work on private and public commissions at Reunion Studios, his fine art's studio that specializes in non-sectarian sacred art.

Journal of Hindu-Christian Studies 28 (2015):11-32 
and physical objects, but their embodied use as well. ${ }^{1}$ This approach also critically examines the visual and sensual regimes that they require, the ways of seeing or "sacred gazes" that may or may not have to do with what adherents say they believe, but are demonstrated in this visual piety. ${ }^{2}$ According to Morgan, the visual culture of religion recognizes that

what believers see is the image as an engaged signifier, not the aesthetic object or curiosity that the connoisseur, art collector, or tourist may see. Vision is a complex assemblage of seeing what is there, seeing by virtue of habit what one expects to see there, seeing what one desires to be there, and seeing what one is told to see there. Parsing these intermingled motives and discerning the cultural work they perform as intermingled is the task of critical scholarship. ${ }^{3}$

This article therefore joins other scholars who are making an effort to correct, refine, and expand analyses that solely rely on text-based forms of mediation of ultimate reality with a critical study of material and visual forms of mediation that sensually materialize that reality for believers. This focus therefore welcomes and even necessitates an interdisciplinary approach to the study of religion and an attention to human bodies in the experience of religious identity formation.

Further, this approach also risks a participatory hermeneutics on the part of the scholar, what Rita sherma calls "an intersubjective hermeneutics" or what Lindsay Jones, in his interpretation of sacred architecture, calls the "ritual-architectural eventfulness" in analyzing sacred objects and trying to faithfully describe the selfunderstandings of the traditions that hold them sacred. ${ }^{4}$ This is a critical attention, not on the objects themselves as putatively possessing a universal meaning apart from their context and reception, but on the sensual and social experience of any willing participant in that sacred space (in the case of architecture); with that sacred object (in the case of visual art or culture); or with wearing that sacred garment (in the case of liturgical or religious clothing). Hopefully, this approach can elevate scholarship above advocacy of a particular religion as superior or above arguing against a particular religion as inferior, revealing the very human and compelling characteristics of any religious way of life on its own terms.

\section{Androgyny in Religious Studies}

In the book Mephistopheles and the Androgyne, Mircea Eliade explores what the German Renaissance thinker Nicholas of Cusa calls the coincidentia oppositorum, or the "coincidence of opposites." Nicholas thinks that God cannot be conceived of rationally, but only in paradox, in mystery, and in contexts that are somehow broader than immediate experience. Eliade calls the "coincidence of opposites" the "mystery of wholeness." It is within this context of wholeness that he examines potential meanings for the concept of the androgyne and the androgynous character of the sacred. Speaking from a religious studies perspective, Eliade and Wendy Doniger state that "androgyny is a much more comprehensive and abstract concept than is implied by the literal image of a creature simultaneously male and female in physical form. To say that God is androgynous is very 
different from saying that God is an androgyne." ${ }^{6}$ Therefore, to speak of God's androgynous character as found in expressions of sacred myth, we are not assigning limited and limiting descriptions of gender or sexuality to notions of divinity. The two scholars suggest that we are dealing with paradoxical depictions of divine wholeness.

Firstly, Eliade and Doniger note that there are religious androgynes that are literal, where male and female sex characteristics are divided either horizontally, as with a Greek statue of Aphroditus (male Aphrodite), who has a female torso and male genitalia; or vertically as with the three-armed androgynous Ardhanāriśvara ("the Lord who is half-woman"), with Pārvatī on the left and Siva on the right. Secondly, one can speak of "good" androgynes that are symbolized in text, ritual, or art that are morally acceptable because they strengthen social structures, conventional gender roles, and cultural values; and there also are "bad" androgyne's that are morally unacceptable because they blur social boundaries and gender roles, and destabilize cultural values. Thirdly, they note a type on which I will focus, which is the difference between the "splitting" androgyne and the "fusing" androgyne. Both kinds are creative in opposite ways. Eliade and Doniger write that the splitting androgyne symbolizes a process of creating order from chaos. Typically, this is symbolized in stories of a sexually undifferentiated creature that in the course of the story splits into two sexes. The splitting androgyne is valued in orthodox religions since they are usually suspicious and/or threatened by the notion of undifferentiated chaos, which the androgyne is said to embody and the splitting is said to correct and to order. On the other hand, the two scholars note that the fusing androgyne is associated with "the mythology of mysticism" where chaos is valued in a positive way and even seen as the goal of existence, where an increase of power, regeneration, and supreme integration might be achieved in the fusing of opposites. In these fusing kinds of myths, the male and the female are barren in isolation, but creative in fusing.

In this article I will compare and contrast two different aesthetic uses of the fusing androgyne found in the Integral Yoga of the Mother and Sri Aurobindo, and the spiritual practice of Clare and Francis of Assisi. As I hope to introduce, both of these practices as lived by their founders used fashion, the arts, architecture, and visual culture as means for spiritual growth towards a fusing androgynous ideal of being human, modeled after their understanding of God in human form, the Avatar or the Christ, respectively.

\section{The Integral Yoga of the Mother and Sri Aurobindo}

1. Introduction

Integral Yoga was founded by a culturally mixed couple in the twentieth century; one from France and the other from India. Mirra Alfassa (1878-1973) was a French Jewish woman of wealthy, atheist parents, who became a guru in India, later called "the Mother" by her Bengali spiritual collaborator, Sri Aurobindo (1892-1950). ${ }^{7}$ As a young person, she was a spiritual seeker and a musician and painter in Paris during the Belle Èpoque. She socialized with avant-garde thinkers and many influential artists in her young adulthood, including Matisse, Rodin, and her husband of eleven years, Henri Morisset, who was a well-known figurative orientalist painter at the time. She 
had a child with Morisset but they divorced in 1908. She married again in 1911 to Paul Richard, a French Reformed Church minister turned lawyer and aspiring politician, who became interested in the occult. It was through Richard that she met Sri Aurobindo in 1914. After WWI, they moved to Pondicherry in 1920 to be with the Yogi, but Richard did not stay, divorcing Mirra.

Mirra felt she had found her real spiritual partner in Sri Aurobindo and stayed to collaborate with him on their spiritual goals. Later in her life in India, she also proved to be a genius administrator of more than eighty departments that eventually became the Sri Aurobindo Ashram, founded in 1926. She was unconventional in her role as a guru in twentieth-century India, wearing make-up, playing tennis, and creating art. She also worked with many ashramites that were artists to assist their growth and visual piety in this context. In fact, from 1920, when she arrived for good in Pondicherry, until a year before she died in 1972, she collaborated with painters in the Ashram to create what she called "the Future Painting," to express creatively her spiritual ideals and to help perfect her consciousness and those of her students in the process.

Aurobindo Ghose, later known as Sri Aurobindo, was born in Calcutta, raised and educated in England, and then returned to British India where he actively worked for India's independence until 1910 when the British authorities sought and failed to secure his permanent imprisonment. He then abandoned his political work and fled to Pondicherry in French India for asylum to live out his days as a guru and yogi. He is now considered by scholars of yoga as one of "the founding fathers of the modern yoga renaissance" with Swami Vivekananda and Shri Yogendra. ${ }^{8} \mathrm{He}$ was an unusually gifted genius who knew many modern and ancient languages from both Europe and India, wrote extensively on many subjects, composed poetry, and used it as a means for spiritual growth. His epic poem Savitri is his masterpiece, an example of what he calls "the Future Poetry." It is based on the story of Sāvitrī and Satyavān in the Mahābhärata, yet changing this tale of conjugal love and duty temporarily conquering death into an epic of masculine and feminine divine principles permanently transforming death into eternal life in a union of supreme divine love fully manifest on Earth. Sri Aurobindo's poem is also a creative record/example of his spiritual practice, since he wrote and rewrote it from 1916 until a few days before he died in 1950 as a means to perfect the form of poetry while also trying to perfect his own consciousness (citta).

Both the Mother and Sri Aurobindo claimed not to be Hindu or founding a Hindu spiritual path, though it would be correct to say that the Integral Yoga is a new religious movement influenced by some Hindu traditions. ${ }^{10}$ It is a discipline that seeks first to join the spirit with God in an ascendant movement of consciousness-ascending to the higher realms of the spirit-and then in a novel descendant approach, to bring back the force and presence of the higher spiritual (called "supramental") planes of consciousness into the body and materiality in order to ultimately transform them in a physical and biological way. This is why the arts are so important in this spiritual practice, since they provide a concrete avenue for this material transformation, both for the artist and for the media involved in the 
creative process. The ultimate goal of this yoga is for matter-even the cells in the tissues of the body-to become immortal and divine in an evolutionary process towards what they called the "supramental manifestation" or the "new creation." ${ }^{11}$ In 1954, the Mother describes this supramental change in the human form, what she sometimes calls "the new being," in an explicitly androgynous way: "The supramental body will be unsexed." 12

\section{The Avatar and the Integral Yoga}

The Gurus teach that this future goal of human being is intimately connected to the work of God in human form, the Avatar, who periodically brings to Earth a new dispensation of human potential when Creation needs it, and always embodies divine love and beauty, which are two powers of God's experience of supreme delight or Ananda. ${ }^{13}$ Sri Aurobindo writes in 1909, "God as beauty, Srikrishna in Brindivan, Shyamasundara, is not only beauty, $\mathrm{He}$ is also Love, and without perfect love there cannot be perfect beauty, and without perfect beauty there cannot be perfect delight." ${ }^{14}$ The Avatar Krșna is the living embodiment of this divine bliss, love, and beauty for Sri Aurobindo, who came to him, as he recounts, to unite with the Yogi's consciousness while he was in prison for terrorist activities against the British Raj in 1909. At the time, he was meditating with the Upanișads and the Bhagavad Gitā. As Sri Aurobindo describes it, the jail and its filthy and ugly condition, the menacing guards, the unfriendly courtroom and all in it became his beloved Krș̣na to his waking spiritual eye: “...it was Sri Krishna who sat there, it was my Lover and Friend who sat there and smiled. 'Now do you fear?' He said, 'I am in all men and I overrule their actions and their words. My protection is still with you and you shall not fear." ${ }^{15}$

In the Yogi's understanding, for the supramental goal of creation to become a living potential in life, God needs first to become this goal in and as creation in order to demonstrate its destiny in this stage of evolution. He writes that there will be other stages of cosmic evolution beyond the supramental that will require different incarnations of God in the future. In this vein, Sri Aurobindo later developed his view about the role of the Avatar between 1916-18. ${ }^{16}$ The Yogi writes, "[The Avatar] is the manifestation from above of that which we have to develop from below; it is the descent of God into that divine birth of the human being into which we mortal creatures must climb; it is the attracting divine example given by God to man in the very type and form and perfected model of our human existence." ${ }^{17}$

For her part, the Mother considered the Avatar necessary for consciousness to grow one more rung up the ladder to spirit without losing touch with matter. In 1930 or '31 she writes, "Each time [the Avatar] adds one more step to the ladder there is a new creation upon earth.... The step which is being added now Sri Aurobindo has called the Supramental; as a result of it, the consciousness will be able to enter the supramental world and yet retain its personal form, its individualisation and then come down to establish here a new creation." ${ }^{18}$ The Avatar, the Mother writes, "does not need to be recognised, he need have no outward power in order to be able to establish this conscious connection. Once, however, the connection is made, it must have its effect in the outward world in the form of a new creation, beginning with a model town and ending with a perfect world." ${ }^{19}$ 
The Mother considered Sri Aurobindo the Avatar Krș̣na come again "to establish here a new supramental creation," "a perfect world." She later said that as "soon as I saw Sri Aurobindo I recognised in him the well-known being whom I used to call Krishna.... And this is enough to explain why I am fully convinced that my place and my work are near him, in India." ${ }^{20}$ Her teaching about this is found powerfully in her use of visual culture, the first of which is in her use of flowers. She named 898 flowers according to the most recent count,

Both the Mother and Sri Aurobindo also had a symbol for their avataric roles that the Mother created, which are the second form of visual culture that shapes the sacred gaze of their devotees (See Figure 1). These emblems are stylized versions of the lotus flowers that she named, and they enshrine the central values of their yoga and their role in it, which are displayed all over the Ashram. The Mother describes her own symbol: "The central circle represents the Divine Consciousness. The four petals represent the four powers of the Mother. The twelve petals represent the twelve powers of the Mother manifested for her work." ${ }^{23}$ and two of them have relationship to their notion of the Avatar. The red lotus flower she calls "Avatar-the Supreme manifest on earth in a body" and the white lotus she names "Aditi-the Divine Consciousness." ${ }^{21}$ Commenting on these flowers, she says, "The red lotus represents Sri Aurobindo, the white one me. In a general way the lotus is the flower of the Divine Wisdom, whatever its colour. But red signifies the Avatar, the Divine incarnated in matter, and white signifies the Divine Consciousness manifested upon earth." ${ }^{22}$

About Sri Aurobindo's symbol the Mother writes: "The descending triangle represents Sat-Chit-Ananda. The Ascending triangle represents the aspiring answer from matter under the form of life, light and love. The junction of both-the central square-is the perfect manifestation having at its center the Avatar of the Supreme-the lotus. The waterinside the square-represents the multiplicity, the creation." ${ }^{24}$ In other places within the Ashram, the union of both symbols are also made and displayed, which the Mother simply writes is "The effective manifestation of Ishvara and Ishvari in union" (See Figure 2).

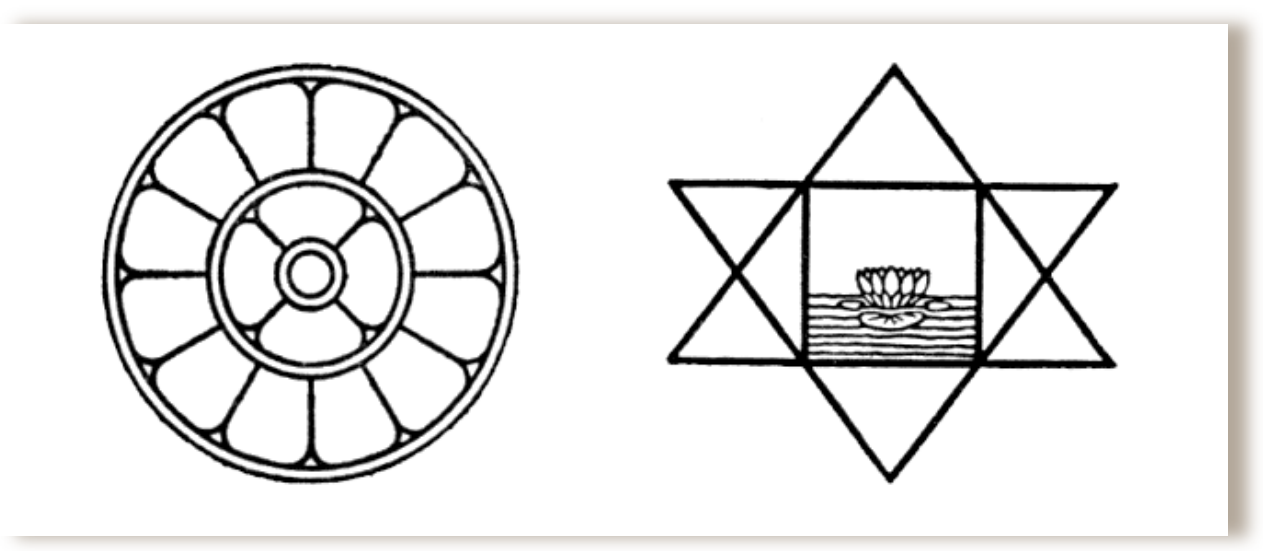

Figure 1. The Mother's and Sri Aurobindo’s symbols, respectively. 

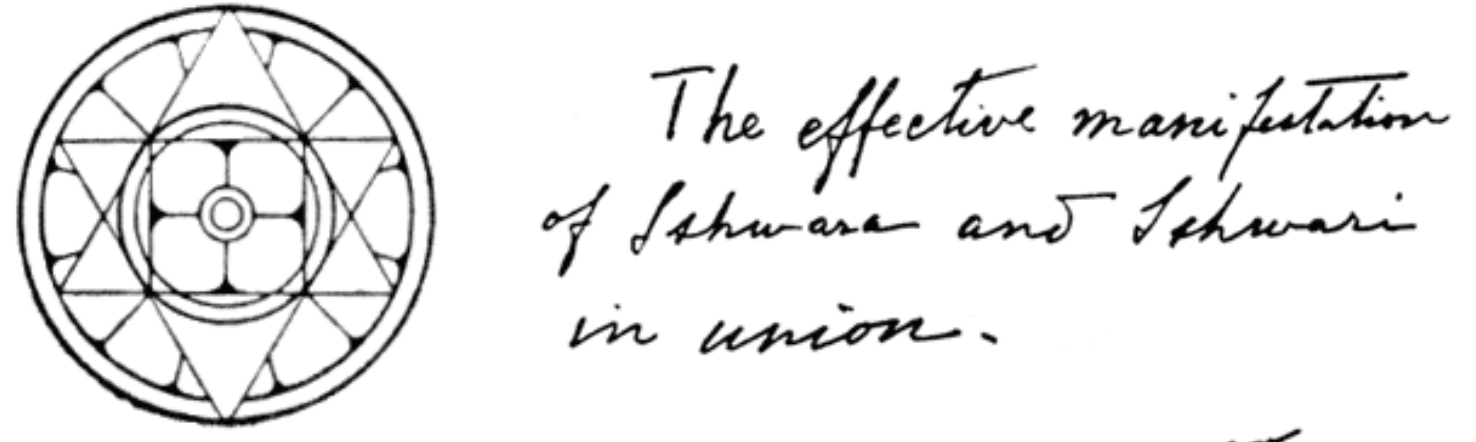

Figure 2. The union of both symbols used as the logo for the Sri Aurobindo Center of Education and also the Ashram Archives and Research. Depicted here with the Mother's handwriting and signature.

The third form of visual culture that I will point out is the Gurus's handwriting. The Mother's and Sri Aurobindo's handwriting is sacred to their devotees, and is often printed in signage and publications as a means to infuse the material it is on with this spiritual value. As the community understands it, the Gurus's teaching is not just in the conceptual content of their written words, but in the divine consciousness that this physical handwriting is felt to hold in text-form (in its style, its shape, its physical presence as coming from their hand). The revelatory power and presence of God in their human form extends to any work of their hand, including their art, their handwriting, and signatures. For these followers, God becomes human in the Gurus, and becomes text in their writings, especially if handwritten.

When the Gurus were alive, the students had a chance to celebrate their gurus in darśan programs that were held on important dates in the community (the arrival of the Mother to Pondicherry, the Gurus' birthdays, the founding of the Ashram, New Years Day, and "The Golden Day," which commemorates the birth of the supramental age). During these lengthy programs, the Mother and Sri Aurobindo would sit together in Sri Aurobindo's apartment as each aspirant passed by and greeted them with a namaskar or other gestures of devotion that allowed them to gaze into their beloveds' eyes. Today these dates are yearly celebrated as times to take darśan in the Main Ashram Building where the two used to 
live in separate apartments, and where they are now buried. The samadhi or tomb-shrine there is filled with a silent and intense atmosphere that is supported by a large shade tree, plants, and flowers. The marble covering of the grave is daily decorated with different beautiful designs made of diverse and colorful blossoms by a creative floral team.

Taking this visual evidence into consideration with the writings of the Gurus, it is not difficult to see why the devotees regard the Gurus together as the "supramental" Avatar come again to bring a new supramental human being in the image of this spiritual couple, who embodies the divine masculine and the divine feminine in human form, Ishvara and Ishvari. In this age, for those in the Sri Aurobindo Ashram, the growth of the future androgynous new creation, the "unsexed" supramental body that all are destined to enjoy in coming births is made possible by the androgynous incarnation of God, who has seeded this potential now in the Mother and Sri Aurobindo.

\section{Visual Art of the Sri Aurobindo Ashram}

Though the Mother rarely painted after she arrived in Pondicherry in 1920 (see figure 3 for an early example in oil she made in Paris), she collaborated with other painters until 1972, a year before she died. For those fifty-two years she tried to use painting in the same way that Sri Aurobindo used poetry: to perfect the basic consciousness (transforming the citta into Brahman's (it) and to see how far that growth could refine and even perfect the art form itself in the process. As Sri Aurobindo experimented with what he called a "Future Poetry" in the poem Savitri for this project, the Mother wanted "to express the Divine Light without shadow in the Future Painting" by painting key episodes of the poem Savitri for her project. $^{25}$ Her chief painting collaborator, Savita "Huta" Hindocha (1931-2011) describes it this way: "But really speaking, the paintings of the whole of Savitri are the Mother's own creation, based not only on her series of visions but also on her own guiding sketches: they are a reflection of her own Yoga." ${ }^{26}$ However, given her role as guru that actively administrated the complex and various activities of the entire Ashram, this "Future Painting" was not possible to complete on her own. Therefore, Huta herself as the Mother's artist, not just her artwork, became the reflection of the Mother's own Yoga. Eventually, the paintings on Savitri that Huta did under the Mother's intimate guidance became a series of 472 oil paintings called Meditations on Savitri. For the Mother and Huta this experiment was the Mother's way of helping the physical world adopt the new creation, by painting it into being using the palette of color that exists in the Mother's visions. The Mother said to Huta in 1956, "I think of expressing [the Higher Worlds] in painting by various colors-blues, golds, pinks and whites-with certain vibrations of Lightall in harmony forming the New World. I wish to bring down upon earth this New World." 27 


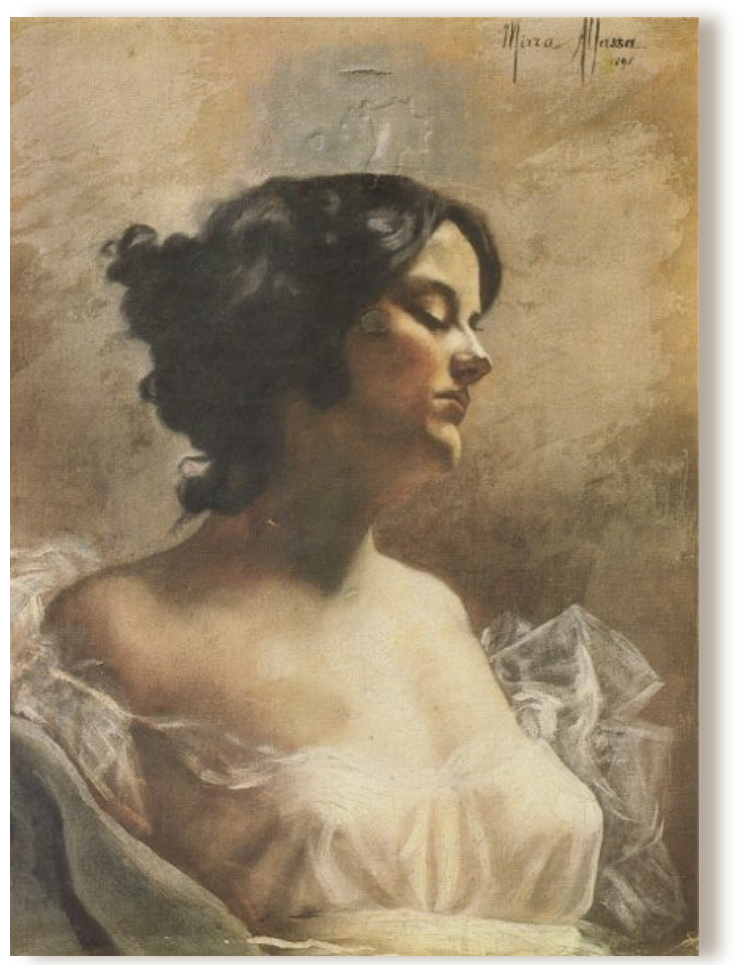

Figure 3. Mirra Alfassa, Early Study, 1895, France.

There is a certain conventional logic to the Mother's inner vision of the colors in the new creation. The Mother describes the supramental world as increasingly lighter blends of gold. (Above this, the realm of Brahman, it is increasingly white and finally transparent like a diamond at its core). When the supramental realm is combined with the physical world, which she says is symbolized by the color red, the result is a kind of bronzy golden orange or golden pink color. In describing the kind of painting that she wanted Huta to do, she trained her gaze to value these colors, white being the most important, which creates pastels: "I want you to do something new. You must try to do the Future Painting in the New Light. There is a reason why I ask you to paint mostly on a white background. It is an attempt to express the Divine Light without shadow in the Future Painting." ${ }^{28}$ It is "without shadow," which may mean that the light source is not exterior, but interior, causing forms to glow from within.

In fact, the characteristics of this light and its the colors also characterize the supramental bodies that the Mother saw (including her own body) in what she called "the subtle physical" realm, which is a kind of hybrid place that bridges the supramental to the physical. When describing Sri Aurobindo's supramental body in 
this realm in the 1960s, she says, "His color is a sort of golden bronze, a color like the coagulation of his supramental gold, of his golden supramental being; as if it were very concentrated and coagulated to fashion his appearance; and it doesn't reflect light: it seems as if lit from within (but it doesn't radiate), and it doesn't cast any shadows." ${ }^{29}$ She also says his clothing and his form are unique in the vision, "he wasn't naked, yet he didn't wear any clothes.... Which means they have a sort of clothing of light. But it doesn't give the impression of a radiating light or anything of that kind. It's like an atmosphere." ${ }^{30}$ Further, his movements are unusual in her descriptions, “when he has to move, he doesn't give the impression of being subject to the same laws as we are; .... he is in several places at the same time. And a plasticity, an adaptability according to the work he wants to do, the people he meets." 31

One of the more important images of the painting series Meditations on Savitri that depicts the new supramental body, is a picture from Book One, Canto One of Savitri, which the Mother began with Huta November 4, $1961 .^{32}$ It is an image of the new creation descending upon earth in the form of androgynous human body, clothed by the colors of pale pink and orange-gold, and based on the following passage from Savitri:

The darkness failed and slipped like a falling cloak

From the reclining body of a god.

Then through the pallid rift that seemed at first

Hardly enough for a trickle from the suns,
Outpoured the revelation and the flame.

The brief perpetual sign recurred above.

A glamour from unreached transcendences

Iridescent with the glory of the Unseen,

A message from the unknown immortal Light

Ablaze upon Creation's quivering edge,

Dawn built her aura of magnificent hues

And buried its seed of grandeur in the hours. $^{33}$

\section{The Androgynous Form of the New Creation in Art}

The Mother describes in The Mother's Agenda her aspiration to join processes that to her seem available on Earth for the first time in history to make her own physical body become supramental before death, to make the very cells of her body wake up to their hidden divinity. She describes how she experiences the cells of her tissue starting to live in a way that even they spontaneously do the Integral Yoga of aspiration, negation, and surrender, independent of her vital and mental natures.

Sri Aurobindo is sanguine about this possibility as well. In his early writings, in his Record of Yoga he records (mainly from 1912-20) his experiments in trying to transform his physical body using different siddhis (occult powers or perfections), one of which is Saundarya (beauty of the body). Sri Aurobindo says that there are three stages of Saundarya. These stages are similar to his images of the supramental beings he describes in the poem Savitri, "the Omnipotent's flaming pioneers," "The sun-eyed children of a marvellous dawn," whose "Bodies [were] made beautiful by the 
The Androgynous Visual Piety of the Mother and Sri Aurobindo and St. Clare and St. Francis 21

spirit's light." ${ }^{34}$ Sri Aurobindo writes that the first stage of this Saundarya siddhi is that the skin would physically become brighter, the voice more sweet, and the gestures more charming. The second is perpetual youth ("The architects of immortality") and the third is the ability to change (without plastic surgery) physical features on the body to be more harmonious in form.

Sri Aurobindo did not achieve these goals or perfect these siddhis, even though he claims to have had some success in terms of brighter skin and sweeter voice, and others in his community at the time even remarked at these physical changes. Still, he never lost sight of the full goal. At the end of his life, between 1949-50, he writes: "A transformation of the body must be the condition for a total transformation of the nature." ${ }^{35}$ His notion of transformation includes the physical body's maintenance and procreativity; in other words, the use of food and the organs for supplying energy in the body, as well as the use of sex and the organs for insuring the future of the species are potential places of transformation. For him, this change means even a diminishment or even disappearance of the current structure of the gastronomic, digestive, and sex organs if a new and supramental instrumentation replaces the operations that current ones fulfill. ${ }^{36}$ The Mother says the same. ${ }^{37}$ In 1954 , she says the following about the sex of the divine body: "The supramental body will be unsexed, since the need for animal procreation will no longer exist. The human form will retain only its symbolic beauty, and one can foresee even now the disappearance of certain ungainly protuberances, such as the genital organs of man and the mammary glands of woman." ${ }^{38}$ She claims in 1972 that Sri Aurobindo also described the body in androgynous terms, but it is not written in any of his texts, so it must be something he discussed with her in person. She says: "Because, according to what Sri Aurobindo said, the supramental body will be immortal and sexless-that is, no procreation." ${ }^{39}$ According to the Mother, "The supramental being as [Sri Aurobindo] conceived of it, is not at all formed in the ordinary animal way, but directly, through a process that for the moment still seems occult to us." 40

At first read, the Mother's and Sri Aurobindo's descriptions seem to be of a human body that has no gross matter, an alaukika (non-worldly) body. However, the Mother tries to counter this thought, as I read her and her partner, as theirs is a negation of all that cannot go forward into the life divine (the limited characteristics of the sattvic, rajasic and tamasic qualities of matter, not matter itself). The new substance of matter will be made up of that supple, golden-pink material she experienced in her visions. She writes: " $[t]$ his does not mean that there will no longer be any definite and recognisable forms; the form will be built by qualities rather than by solid particles. It will be, if one may say so, a practical or pragmatic form; it will be supple, mobile, light at will, in contrast to the fixity of the gross material form." ${ }^{41}$

\section{The Privelege of Poverty of Clare and Francis of Assisi}

\section{Introduction}

In the Christian tradition, there are comparable examples of spiritual androgyny that possess fusing attributes. Joan Mueller notes that "[t]heologies of spiritual complementarity between sexes patterned on 
the eschatological vision of Galatians 3:28, 'in Christ there is neither male nor female,' were common in the eleventh and twelfth centuries." ${ }^{42}$ We can amplify the theological description of this time period with a brief visual culture analysis. In this second part of the article, I will focus on two twelfth- and thirteenth-century saints, and their use of fashion, art, architecture, and visual culture that expresses an androgynous ideal of both Christ and human fulfillment. Chiara di Favorone di Offreduccio (1193/94-1253) and Giovanni "Francesco" di Pietro di Bernardone (1181/82-1226) arguably brought this medieval eschatological vision of Galatians to an intensity that had never been reached before in the Catholic Church nor since, and provides a comparable ideal of androgyny to the spiritual practice of the Gurus from Pondicherry.

The original Italian context of Franciscan spiritual practice was one of great social change: the traditional European feudal order was challenged by the rise of the new merchant class. Clare, a noble, and Francis, a son of a wealthy merchant, renounced their high station in society. They rejected both new and old forms of economic relationships that insure exclusivity, and the common and growing desire to possess anything of one's own, to be sine proprio; to live what Clare later called "the privilege of Poverty." They sought to join creation and the disenfranchised in what they saw as an imitation of the Christ and Mary. Franciscan spirituality as lived by Clare and Francis is, therefore, a spiritual approach that seeks the material transformation of reality. Unlike the Pondicherrian Gurus, the Assisians did not teach a physical transformation of creation that involved a new species of human being. However, their practice is indeed an important prototype of the Integral Yoga that shares a full understanding of the role of opposition in the process of spiritual growth, an inclusive and universal affirmation of the world, while honoring very broad forms of love, beauty, and bliss, or what Francis called la vera e perfetta letizia (true and perfect joy) as the goal and destiny for all creatures. ${ }^{43}$

\section{The Androgynous Fashion of God's Love}

Both Clare and Francis valued artistic expression specifically made in praise of Jesus and Mary. Francis rebuilt churches, as we will discuss, he was a preacher, sang troubadour songs in praise of his ideal, "Lady Poverty," and performed as an actor with others on the streets of Umbrian towns, even reenacting the Nativity in the town of Greccio. Lastly, Francis was also a poet, as his poem Canticle of Brother Sun demonstrates. We do not have evidence that Clare was as expressive in this way as Francis, but she was a spinner of thread used for weaving liturgical linens and garments; she sewed together her own hooded tunic as an important form of fashion that expresses her spiritual ideals, and like Francis, wore it to subvert exclusive forms of status (See Figures 4 and 5). Like any culture, dress in Assisi "was an immediate give-away of status. Francis earliest biographers cleverly play on this standard marking each step in his spiritual development by a change in attire." ${ }^{44}$ One could say the same of Clare, as she changed her clothes as she changed her role in life. Like Francis, the style of her hair is also significant in this way, as it amplified the visual communication of her identity. Clare had her hair cut in a "tonsure" ceremony both as a means to surrender to God and to join Francis's work, and more practically, to achieve "safety from her 


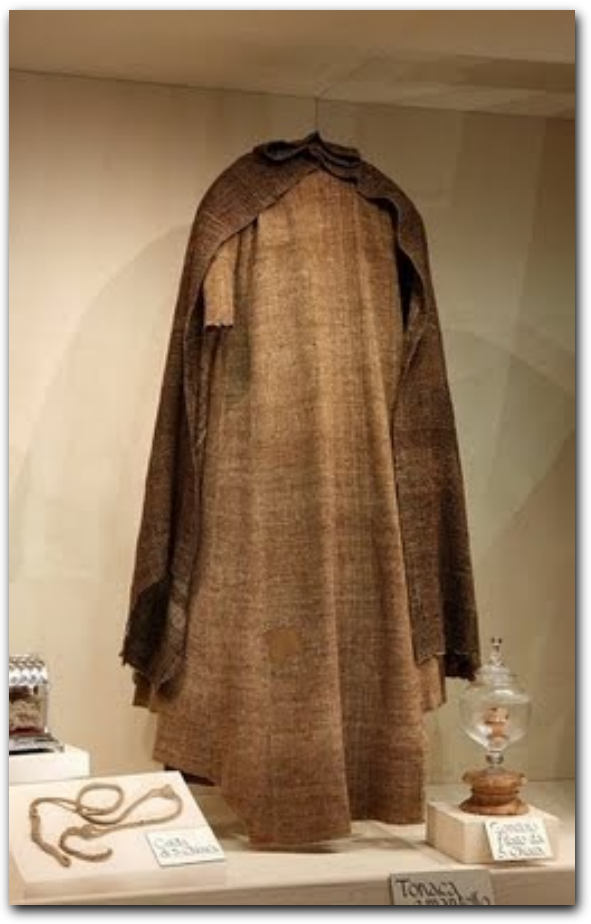

Figure 4. Tunic of Clare of Assisi. http://dlandcatholic.blogspot.com/2 012/08/st-clare-of-assisi.html, accessed 10.24.14.

relatives." ${ }^{45}$ Because her family was seeking to marry her to a local noble, in cutting her hair, this "damage" to her beauty put her off the market. Ultimately, I think it also expresses the androgynous visual piety that I see in this couple. Her tonsure was a way to position socially assigned gender roles below a spiritual identity of the soul, which cannot be reduced to a gender.

Fashion played a role to join her to her ideal on her deathbed, as well. One of Clare's disciples, Sister Benvenuta, testified during Clare's canonization proceedings that she saw the Virgin Mary and her Court of Virgins come to Clare to dress her in a new divine garment as a preparation for her coming encounter with Jesus and Francis. She writes that the most beautiful of the court came and "covered

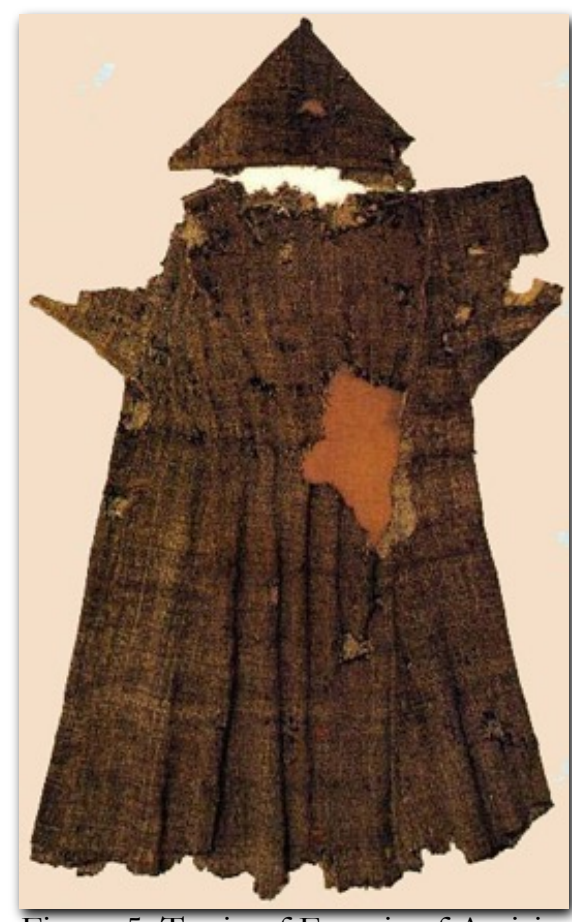

Figure 5. Tunic of Francis of Assisi in which he received the stigmata. http://www.integratedcatholiclife.or $\mathrm{g} / 2011 / 08 /$ sr-marie-morgan-dirtyhabits/, accessed 10.24.14.

[Clare's] bed with the most delicate cloth so fine that, even though she was covered with it, Lady Clare nonetheless saw through its great delicacy." 46

Francis used fashion throughout his life. Earl Brandon Strehlke writes that in his youth, Francis "passed all limits in dress. He had the most sumptuous clothes made up even if they were not fitting to his social condition, and, in his search for originality he even sewed together in the same piece of clothing precious textiles with course ones." ${ }^{47}$ This impulse to sew diverse textiles together relates to his later impulse to join other more significant poles of reality: the rich and the poor, the mainstream with the marginalized, the female and the male, divinity and creation. His first encounter with a 
leper captures this drive to unite opposites within himself. Francis writes, "while I was in sin it seemed very bitter to me to see lepers, and the Lord Himself lead me among them and I showed mercy to them. And when I left them, that which seemed bitter to me changed into sweetness of soul and body." ${ }^{48}$ This is Francis's quintessential teaching about "the mystery of wholeness," progressively seeing the inclusive beauty of all creation.

After his conversion to Christ's inclusive vision, Francis donned a hooded farmer's tunic. His inspirations for this were the local peasants in the valley who wore it, the crested lark and its earth-colored plumage, and the cross of Christ. Francis's peasant tunic seems to have been a fashion statement meant to deconstruct gender, class, and religion so that a "new Adam" might be experienced in the life lived in these clothes. His first and last use of fashion in his ministry, in fact, was in a via negative-to take the tunic off. When he formally left home, he took off his clothes that his father provided, to seek his spiritual father. Years later, right before he died, he had his brothers strip him naked so that he could die touching the Earth.

Fashion both covers and reveals the bodies and spiritual ideals of these spiritual partners for their disciples. As Clare was covered by the Virgin to reveal her unity with the Madonna, Francis was stripped to reveal his union with his naked and crucified Lord.

\section{From Fission to Fusion in the House of God}

Interestingly, Catherine Mooney points out that Francis never used the word "father" for himself or his brothers, the Friars Minor. "Father" is reserved only for God in his writings. Mooney writes that "Francis of Assisi ...stands out among male saints for the ease and frequency with which he speaks of himself and other men as mothers." ${ }^{49}$ Mooney traces the way Francis and others speak about himself as both woman and man in his letters, his Rules, and in subsequent biographies by others. She writes that " $[\mathrm{m}]$ others, according to Francis, are not, like father, hierarchically positioned above brothers. They are not authority figures at all." ${ }^{50}$ In fact, as Regis Armstrong states, Francis's regard for women came before his regard for men when planning for his new inclusive community. Armstrong writes, "Francis was more certain at that early period [before he met Clare] of helping to establish a monastery of women than a religious order of men." ${ }^{51}$

One can see the influence of Francis's relationship to his own father, who could not understand him and was violently domineering and abusive; and to his mother, who tried to protect Francis from his father's rages yet had no authority in the house. Francis's experience of fission with his parents had a role to play, it seems to me, in stimulating his vision of fusion in three Orders that included both sexes and all classes (the Friars Minor, the Poor Ladies, and the Third Order of lay members). It brought about Francis's kind treatment of weaker men, of women, and of animals expressing a new way of being human, which Mooney calls androgynous.

What I would call the androgynous ideal in Franciscan spirituality seems both a splitting and a fusing type of androgyny. Clare's and Francis's spiritual practice is based in Hebrew and Christian sacred writings, which value and seek to maintain the splitting androgyne in Genesis and the Song of Songs, yet describe God in both male and female imagery in the Wisdom literature, for example, which is more 
The Androgynous Visual Piety of the Mother and Sri Aurobindo and St. Clare and St. Francis 25

indicative of the fusing androgyne. Biblical scholar Phyllis Trible translates the Hebrew word hā-'ādàm in Genesis 2-3 as "earth creature," who is the sexually undifferentiated human being that Yahweh creates in the myth. In the Jahwist creation account, God splits hāa' $\bar{a} d \bar{a} m$ into two and therefore introduces the possibility of relationship and love between Adam and Eve, the first sexed human beings. ${ }^{52}$ As the well-known story goes, this relationship goes awry and punishment ensues; punishment in the form of patriarchy, as Trible argues. The potential of divine grace to heal these relationships so that love once again rules in mutuality and equality is a foretaste that Trible sees in the Song of Songs. This healed mutuality between the sexes is elevated for the Christian, I suppose one could say, in the culminating, eschatological androgynous fusing in Christ, the "new Adam" or the new sexually undifferentiated "earth creature," using Trible's hermeneutical lens. This new earth creature, created and redeemed in the image of the Christ, is one that is expected in the fullness of time or the end of history, whereas the "new being of the new creation" in the view of the Mother of the Sri Aurobindo will become endemic on Earth beginning in the next three hundred years..$^{53}$

In the lives of Clare and Francis, the splitting androgyne was present in the art of their neighborhood, not only in their sacred texts. We can see this in a relief sculpture completed in the early 1200s in the central portal of San Ruffino church in Assisi. This relief is called "Christ Enthroned with the Sun and Moon and the Nursing Virgin (See Figure 6)." This church is significant because it is where both Clare and Francis were baptized and where Clare heard Francis preach in 1209 and decided to follow him. It is not clear if and when they saw this relief, but it might have helped to shape the visual regimes of these two people since it adorned a building special to them. The lunette depicts Jesus in between the sun and the moon, while Mary is nursing a child on the moon side and San Ruffino stands in attendance on the sun side. Masculinity is clearly separated from femininity in this image, just as the sun and the moon are separated by the Christ, who we could say, is still an image of their unity, since he is positioned in the undifferentiated round center. 


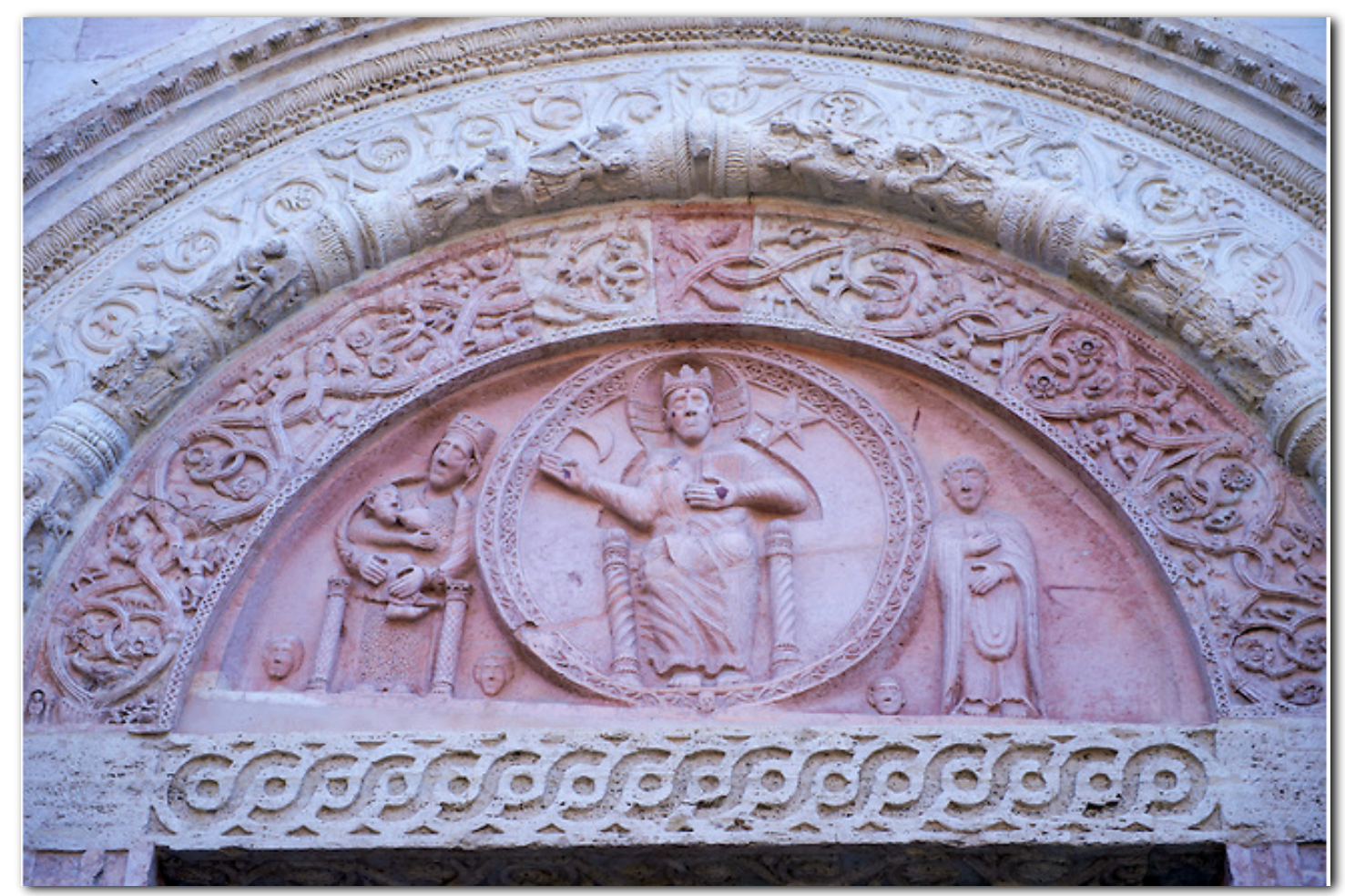

Figure 6. "Christ Enthroned with the Sun and the Moon and the Nursing Virgin," early 1200s, pink limestone, Assisi Cathedral, Italy.

http://funkystock.photoshelter.com/image/I0000IVLTsXmrnS8, accessed 8.4.14.

We can contrast this spitting image of the androgyne with a fusing image of androgyny that Clare experienced in a vision later called "The Vision of the Breast of Saint Francis." Sometime after Francis died and later in Clare's life, she had a vision that four of her sisters testified to in the proceedings for Clare's canonization. ${ }^{54}$ In this vision, Clare saw Francis and effortlessly ran up to him over stairs with a bowl of hot water and a towel to dry his hands. Francis exposed his breast and told clare to "come, take and drink." she did. A second time, he invited her to drink, and the milk was indescribably sweet. The account goes on to say that his nipple was also a mouth that clare held between her lips, and that the milk that she drank became golden liquid as she placed it in her hands. It was a gold so clear and bright that she saw everything in creation within it as one sees in a mirror. Marco Bartoli notes that this vision has psychological implications: Clare "looks at herself in the Francis she has possessed, and she sees herself there." ${ }^{55}$ More than possessing Francis, as would a breastfeeding baby in the Freudian oral phase of psychological development, Bartoli argues that Clare identifies with her beloved in this image. He also notes the literary importance of the mirror, which in this culture's imagination is a symbol of mystical union. Catharine Mooney corroborates this view and writes that the holding of "his nipple, revealingly called the 'mouth' of his breast, in her mouth is more intimate than a kiss. She sucks his blood-milk 
The Androgynous Visual Piety of the Mother and Sri Aurobindo and St. Clare and St. Francis 27

and, in a sense, becomes Francis as his fluid becomes part of her own body." ${ }^{56}$ It seems to me that in this vision the two become one, and the unity is a sexually undifferentiated new "earth creature," an alter adam. Further, Mooney links this vision of Clare with Francis's experience of the stigmata, which Thomas of Celano, Francis's first biographer, calls a "sacrament" and a conformation of his being alter christus. Mooney writes that "[w]hen Clare sucks Francis's breast, she is in a sense recognizing his association with Christ, confirming in another way Celano's claim that Francis's stigmata was a sacrament." ${ }^{57}$ In medieval Franciscan literature and iconography about Mary and Christ, milk and blood are related in interesting ways, which tend to symbolize the Eucharist, Jesus's Passion, and Mary's role in his mission as both divine mother and co-redemptrix. As Mary nursed Jesus, her milk became his body and blood, which in turn became the Eucharist to nourish the growth of the church as it was shed on the cross. ${ }^{58}$ Francis and Clare expand this bodily participation in salvation history in Clare's vision.

Clare and Francis both inspired a reversal of the spitting androgyne that was chiseled into stone on San Ruffino church in their own innovative use of architecture. The "privilege of poverty" started with Francis's call to rebuild the church, to rebuild what they called the "House of God." The image of the House of God had a physical reality in the first churches that Francis rebuilt: San Damiano and the Portiuncula chapel ("the little portion," which might be translated colloquially as "home sweet home"). It had communal and psychological reality in the three Orders that he founded for men, women, and laity. For instance, Francis's first rebuilding project was San Damiano, a structure that was originally meant to support male priests and the sacraments that they officiate. After he built San Damiano, he filled this structure with women, with Clare and her Poor Ladies, reorienting the structure's use and meaning. The "House of God" had social, political, and religious reality in the Catholic Church that he and Clare sought to reform. Catherine Mooney writes, "Mirroring his repair of San Damiano, Francis brings into this universal church the opposite virtues of humility and poverty. Into this very male and fatherly church, Francis introduces conventionally feminine features." ${ }^{59}$ Mooney suggests that the androgynous quality that Francis embodied himself was a catalyst for the Church as a whole, for "Francis renewed the church, according to Celano, by introducing into it feminine qualities, transforming an eminently male institution into a more androgynous institution." ${ }^{60}$

Finally, the "House of God" had spiritual reality in the new Garden of Eden that they tried to evoke as a spiritual practice with their companions. Though they would not have shared Trible's twentieth-century reading of Genesis, it would seem this spiritual reality is related to the sexually undifferentiated $h \bar{a}-$ 'àdām or earth creature in the New Eden. The way that Clare and Francis tried to order their lives in San Damiano, the two were "thrown together," or "co-incided" in Armstrong's words. Armstrong writes, that this "coincidence" was made possible "by Francis in his enterprise of rebuilding materially that small church San Damiano; by Clare in making of it a 'school' of poor contemplative women learning to carry out [its] activities." ${ }^{61}$ In other words, in their distinct yet complementary charisms of 
the spirituality of poverty that found expression in rebuilding the "House of God," Francis and Clare manifest the coincidence of opposites, what Eliade called "the mystery of wholeness." At the center of this wholeness is the God-Man, crucified on the San Damiano Cross that inspired Francis in the first place to rebuild the church, and became the central image in Clare's prayer life and in her advice to others in her letters.

\section{Conclusion}

The human body of the new supramental creation as seen in the spiritual visions of the Mother embodies an androgynous goal of human aspiration in the Integral Yoga. Clare's vision of the new 'ādam or "earth creature" in the form of the mothering and nursing Francis seems to be the androgynous goal in Franciscan spiritual practice. Both of these androgynous ideals for human growth are linked with an experience of God in human androgynous form. Krșna is the ideal for the Mother and Sri Aurobindo, and the Gurus themselves are the ideal for their followers, making both male and female characteristics a central part of their sacred gaze. Mary and Jesus are the spiritual ideal of wholeness for Clare and Francis, while Clare and Francis became this androgynous ideal of wholeness for their followers.

Though they are distinct, both spiritual practices share some key elements in the visual regime or sacred gaze that they require. I have focused on the element of the "fusing androgyne," taking Eliade's use of the word to be evocative of spiritual, social, and even physical wholeness. The sacred gaze of the Integral Yoga is a descendant non-sectarian way of seeing, one that focuses on the body and its transformation into a new supramental being of the new creation, who lives God's life on Earth. This life is androgynous in their view, since it unites and includes both sexes as it integrates all other opposites. The Mother's painting and Sri Aurobindo's poetry express this fusing androgynous ideal. We can also see it in their use of visual culture: the lotus flowers, their symbols, their handwriting, and darśan programs, which not only celebrate this ideal but train their devotees to view the Gurus as its Avatars. In their understanding, the Avatar's role is to awaken people to their own divine identity and destiny, to pressure them to work for its manifestation in their own cittas or basic consciousness, which has ultimate effect in the physical body. We briefly studied the Mother's painting with Huta as an example of this pressure for growth. The colors and the human forms they painted express the androgynous ideal that Huta sought to become and that the Mother and Sri Aurobindo embody for Huta.

In comparison, Clare and Francis's work to unite with all classes and all creatures in order to share their experience of "true and perfect joy" expresses their version of this universal sacred gaze. They "clothed themselves with Christ," "putting on the new man" by the fashion they wore and the garments they used in caring for those on the margins of Umbrian society. ${ }^{62}$ In rebuilding San Damiano and the Porziuncola chapel, they built structures to house God's androgynous life that coincides all opposites, fusing male and female in a new earth creature, a new Adam who can walk naked with God on the Earth "at the breezy time of the day" without hiding in shame. ${ }^{63}$

In this brief space I can only introduce the textual and visual support that demonstrates and compares the androgynous aesthetic ideals 
as embodied by the two couples and the sacred gaze that they inspire. There are many other artistic avenues for research that can be discussed that would amplify my argument: Francis's Canticle of Brother Sun in comparison with Sri Aurobindo's Savitri; the Mother's use of flowers and Clare's and Francis's value for the natural world; a comparison of Franciscan use of fashion with the Mother's use of fashion and cosmetics; a comparison of Franciscan use of architecture with the Mother's and Sri Aurobindo's Golconde Dormitory in the Ashram and Matrimandir in Auroville; and a comparison

\section{Notes}

${ }^{1}$ David Morgan, Visual Piety: A History and Theory of Popular Religious Images (Berkeley, CA: University of California Press, 1998), 1.

${ }^{2}$ See David Morgan, The Sacred Gaze: Religious Visual Culture in Theory and Practice (Berkeley: University of California Press, 2005), which covers the sense of sight; and more recently David Morgan, The Embodied Eye (Berkeley: University of California Press, 2012), which analyzes other senses with sight as participating in mediating ultimate reality.

${ }^{3}$ Morgan, The Sacred Gaze: Religious Visual Culture in Theory and Practice, 74.

${ }^{4}$ See Rita D. Sherma's "A Hermeneutics of Intersubjectivity," Woman and Goddess in Hinduism ed. Tracy Pintchman and Rita D. Sherma (New York: Palsgrave Macmillan, 2011), 1-16; and Lindsay Jones, The Hermeneutics of Sacred Architecture, Volume One/Monumental Occasions: Reflections on the Eventfulness of Religious Architecture and Volume Two/A Morphology of Ritual Architectural Priorities (Cambridge, MA: Harvard University Press, 2000). of Francis's reenactments of Christ's Nativity and Passion (the Stations of the Cross) with the plays that the Mother wrote and staged in the Ashram. Even without these additional comparisons, however, it is clear that the Mother and Sri Aurobindo and Clare and Francis of Assisi used the arts, architecture, fashion, and visual culture in their spiritual practices to express "the mystery of wholeness" in the fusing of masculine and feminine poles of experience to achieve a new human experience of God on Earth.

${ }^{5}$ Mircea Eliade, Mephistopheles and the Androgyne trans. J. M Cohen (New York: Sheed and Ward, 1965), 80. This same book was published in England under the title The Two and the One. See also Wendy Donger, "Androgynes," in Women, Androgynes, and Other Mythological Beasts (Chicago: University of Chicago Press, 1980), 283-334.

6 Eliade and Doniger, "Androgynes," Encyclopedia of Religion, ed. Lindsay Jones, Vol. 14, 2nd ed. (Detroit: Macmillan Reference, 2005): 337.

${ }^{7} \mathrm{I}$ am assuming Karen Pechelis definition of a guru as someone who "is understood to experience the real continuously;" the "real" being the experience of Brahman. Further, the "guru is able to inspire the experience of the real in others, for the purposes of spiritual advancement, total self-realization, or evolution as a human being." [The Graceful Guru: Hindu Female Gurus in India and the United States (Oxford: Oxford University Press, 2004), 4-5]. This definition compares with the Mother's and Sri Aurobindo's understanding of the role. Sri Aurobindo writes, "The Guru may sometimes be the Incarnation or World-Teacher; but it is 
sufficient that he should represent to the disciple the divine wisdom, convey to him something of the divine ideal or make him feel the realised relation of the human soul with the Eternal." [Sri Aurobindo, Synthesis of Yoga, (Pondicherry: Sri Aurobindo Ashram Press, 1999), 66].

${ }^{8}$ Mark Singleton and Ellen Goldberg, Gurus of Modern Yoga (New York: Oxford University Press, 2014), 9.

9 See Sri Aurobindo, The Future Poetry (Pondicherry: SAAP, 1997).

${ }^{10}$ Sri Aurobindo identified as a Hindu in his political phase from 1901-12, though this had nothing to do with traditional religious practices. See Peter Heehs, "Sri Aurobindo and Hinduism" AntiMatters 2, no. 2 (2008): 33-45.

11 See Sri Aurobindo, "The Supramental Manifestation Upon Earth" in Essays in Philosophy and Yoga (Pondicherry: Sri Aurobindo Ashram Press [SAAP], 1998), 517-92. The Mother mentions "the new creation" about 144 times in her writings, but a brief, though full account of her understanding of this and how it relates to the Avatar can be found in the Mother, "The Supramental Realization," in Questions and Answers 1929-31 (Pondicherry: SAAP, 2003), 178-9.

12 The Mother, Words of the Mother III (Pondicherry: SAAP, 2004), 281-82.

${ }^{13}$ See Bhagavad Gitā 4,7.

14 Sri Aurobindo, Early Cultural Writings (Pondicherry: Sri Aurobindo Ashram Press, 2003), 443. Syammasundara is "the Dark and Beautiful One," an epithet of Krșna. See Bhagavad Gitā 4,7.

${ }^{15}$ Sri Aurobindo, Karmayogin, (Pondicherry: Sri Aurobindo Ashram Press, 1997), 7.
16 See "The Possibility and Purpose of Avatarhood" and "The Process of Avatarhood" in Essays on the Gita (Pondicherry: Sri Aurobindo Ashram Press, 2003) 145-67.

${ }^{17}$ Essays on the Gita, 157.

${ }^{18}$ The Mother, "The Supramental Realization," in Questions and Answers 1929-31, 178-9.

${ }^{19}$ Ibid., 179.

20 The Mother, Words of the Mother I (Pondicherry: SAAP, 2004), 39.

${ }^{21}$ The Mother, The Spiritual Significance of Flowers, Part 1 (Pondicherry: SAAP, 2000), 5 and 3 respectively.

${ }^{22}$ Ibid., 1.

${ }^{23}$ http://www.sriaurobindoashram.org/ashram /mother/symbol.php. Accessed January 24, 2011.

${ }^{24}$ Ibid.

${ }^{25}$ Huta, "My Savitri Work with the Mother," Invocation 12 (August 2001): 8.

${ }^{26}$ Huta, "My Savitri Work with the Mother," Invocation 13 (November 2001): 12.

${ }^{27}$ Ibid., 13.

${ }^{28}$ Ibid., 8.

${ }^{29}$ The Mother, The Mother's Agenda IV, (Paris: Institute de Recherches Évolutives, 1979), June 29, 1963.

${ }^{30}$ The Mother, The Mother's Agenda VII, (Paris: Institute de Recherches Évolutives, 1980), September 14, 1966.

${ }^{31}$ The Mother, The Mother's Agenda VI, (Paris: Institute de Recherches Évolutives, 1980), June 18, 1965. See The Mother, The Mother's Agenda I, (Paris: Institute de Recherches Évolutives, 1978), February 3, 1958 for a lengthy description of her own body and those of other beings helping to bring the supramental world increasingly closer to this plane of life. See also The Mother, Notes on the Way, (Pondicherry: 
The Androgynous Visual Piety of the Mother and Sri Aurobindo and St. Clare and St. Francis 31

SAAP, 2002), 238, July 1, 1970; and Notes on the Way, 301-2, March 24, 1972 and March 25, 1972 for a small selection of other references.

${ }^{32}$ As I was not given permission by the Trust who cares for Huta's paintings to publish any image from this series, I direct the reader to YouTube, where a clip of the DVD made for this series is published and briefly shows an image of the painting under consideration: https://www.youtube.com/watch?v=QGGc4vK VrZ8 (Start at 2:57-3:24).

${ }^{33}$ Sri Aurobindo, Savitri: A Legend and a Symbol (Twin Lakes, WI: Lotus Light Publications, 1995), 3.

${ }^{34}$ Sri Aurobindo, Savitri, 343-344.

${ }^{35}$ Sri Aurobindo, "The Divine Body" in Essays in Philosophy and Yoga (Pondicherry: SAAP, 1998), 537.

${ }^{36}$ See the entire chapter "The Divine Body," in Essays in Philosophy and Yoga, 536-57, where he details his view about the potentials supramental changes to the body living a life divine.

${ }^{37}$ See the Mother, Questions and Answers, 1953, 59.

38 The Mother, Words of the Mother III (Pondicherry: SAAP, 2004), 281-82. If one watches fashion trends and the bodies of models, this comment might seem possible. Androgyny seems a perennial theme in modern fashion. Just this season, www.style.com noted it as an important trend in men's fashion. See http://www.style.com/slideshows/slideshows/ trends/mens/2015/2-february/menswearrunway-trends-fall-2015/slides; (accessed 2.19.15)

${ }^{39}$ The Mother, The Mother's Agenda, XIII, (Paris: Institute de Recherches Évolutives, 1981), August 9, 1972.
${ }^{40}$ The Mother, Questions and Answers, 1957-58 (Pondicherry, SAAP, 2004), 190.

${ }^{41}$ The Mother, Questions and Answers, 1953, 60.

${ }^{42}$ Joan Mueller, A Companion to Clare of Assisi: Life, Writings, and Spirituality (Leiden: Brill, 2010), 69.

${ }^{43}$ Ernesto Caroli, ed., "Della Vera e Perfetta Letizia," Fonte Francescane (Padova, Italia: Editrici Francescane, 2004), 278:1-15, pp. 19394.

${ }^{44}$ Earl Brandon Strehlke, "Francis of Assisi: His Culture, His Cult, and His Basilica," in The Treasury of Saint Francis of Assisi, ed. Giovanni Morello and Lawrence B. Kanter, trans. Christopher Evans and Richard Sadleir (Milan: Electa, 1999), 24.

${ }^{45}$ Mueller, 27.

46 "Acts of the Process of Canonization of Clare," in Clare of Assisi: Early Documents ed. and trans. Regis J. Armstrong, O.F.M. Cap. (New York: New City Press, 2006), 182.

${ }^{47}$ Earl Brandon Strehlke, "Francis of Assisi: His Culture, His Cult, and His Basilica," in The Treasury of Francis of Assisi, ed. Giovanni Morello and Lawrence B. Kanter, trans. Christopher Evans and Richard Sadleir (Milan: Electa, 1999), 24.

${ }^{48}$ Francis of Assisi, “Testiment (1226)" Francis of Assisi: The Saint, Early Documents, ed. Regis Armstrong, O.F.M. Cap., J.A. Wayne Hellman, O.F.M. Conv., William J. Short, O.F.M. (New York: New City Press, 1999), 124.

${ }^{49}$ Catherine M. Mooney, "Francis of Assisi as Mother, Father, and Androgynous Figure," in The Boswell Thesis: Essays on Christianity, Social Tolerance, and Homosexuality, ed. Mathew Kueler (Chicago, IL: University of Chicago Press, 2006), 301.

${ }^{50}$ Ibid., 308. 
32 Patrick Beldio

51 Regis Armstrong, Clare of Assisi: Early Documents, 408.

${ }^{52}$ See Phyllis Trible, "Depatriarchalizing in Biblical Interpretation," JAAR 41, 1 (March 1973): 30-48; and God and the Rhetoric of Sexuality (Philadelphia: Fortress Press, 1988).

${ }^{53}$ See The Mother, Questions and Answers 1953 (Pondicherry: SAAP, 2003), 58).

${ }^{54}$ See "Acts of the Process of Canonization of Clare," in The Lady: Clare of Assisi: Early Documents, 3:93-98, 4:51, 6:37 and 7:10.

${ }^{55}$ Marco Bartoli, "Historical Analysis and Psychological Interpretations of a Vision of Clare of Assisi," trans. Madonna Balestrieri , O.S.F. Greyfriars Review 6, 2 (1992): 197.

${ }^{56}$ Mooney, "Francis of Assisi as Mother, Father, and Androgynous Figure," 323.

${ }^{57}$ Ibid., 322.

${ }^{58}$ See Caroline Walker Bynum, Holy Feast and Holy Fast: The Religious Significance of Food to Medieval Women (Berkeley: University of California Press, 1987).

${ }^{59}$ Ibid.

${ }^{60}$ Mooney, "Francis of Assisi as Mother, Father, and Androgynous Figure," 316.

${ }^{61}$ Regis Armstrong, O.F.M., "Hermes and the 'Co-Incidence' of San Damiano" Franciscan Studies 66 (2008): 443.

${ }^{62}$ Gal 3: 27 and Eph 4: 24.

${ }^{63}$ Gen 3:8. 